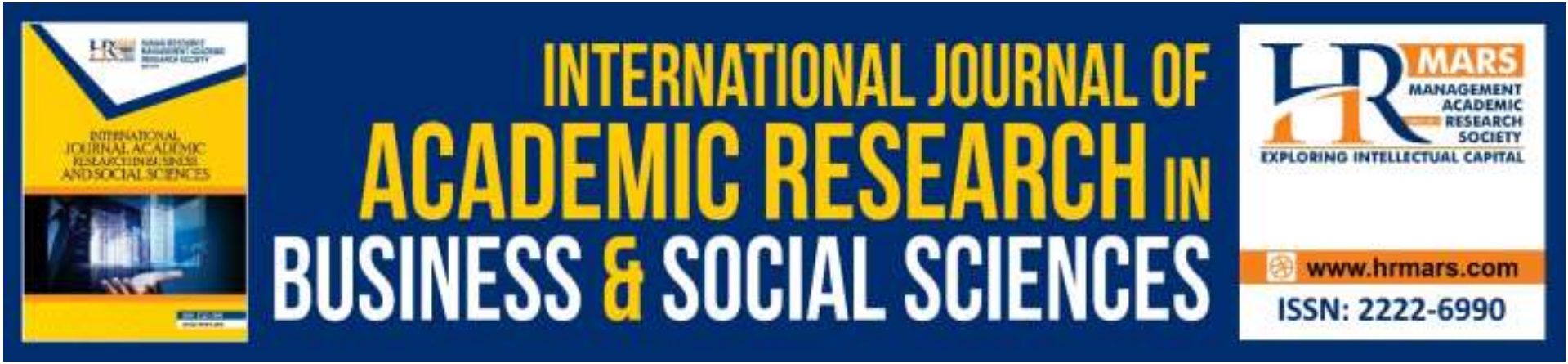

\title{
Framework of Empowering Mosque Institution in Malaysia
}

\author{
Nizaita Omar, Zulkifly Muda, Razi Yaakob, Kasyfullah Abdul Kadir
}

To Link this Article: http://dx.doi.org/10.6007/IJARBSS/v9-i9/6367

DOI: $10.6007 /$ IJARBSS/v9-i9/6367

Received: 02 August 2019, Revised: 20 August 2019, Accepted: 02 September 2019

Published Online: 25 September 2019

In-Text Citation: (Omar, Muda, Yaakob, \& Kadir, 2019)

To Cite this Article: Omar, N., Muda, Z., Yaakob, R., \& Kadir, K. A. (2019). Framework of Empowering Mosque Institution in Malaysia. International Journal of Academic Research in Business and Social Sciences, 9(9), 753-762.

\section{Copyright: (C) 2019 The Author(s)}

Published by Human Resource Management Academic Research Society (www.hrmars.com)

This article is published under the Creative Commons Attribution (CC BY 4.0) license. Anyone may reproduce, distribute, translate and create derivative works of this article (for both commercial and non-commercial purposes), subject to full attribution to the original publication and authors. The full terms of this license may be seen at: http://creativecommons.org/licences/by/4.0/legalcode

\section{Vol. 9, No. 9, 2019, Pg. 753 - 762}

Full Terms \& Conditions of access and use can be found at http://hrmars.com/index.php/pages/detail/publication-ethics 


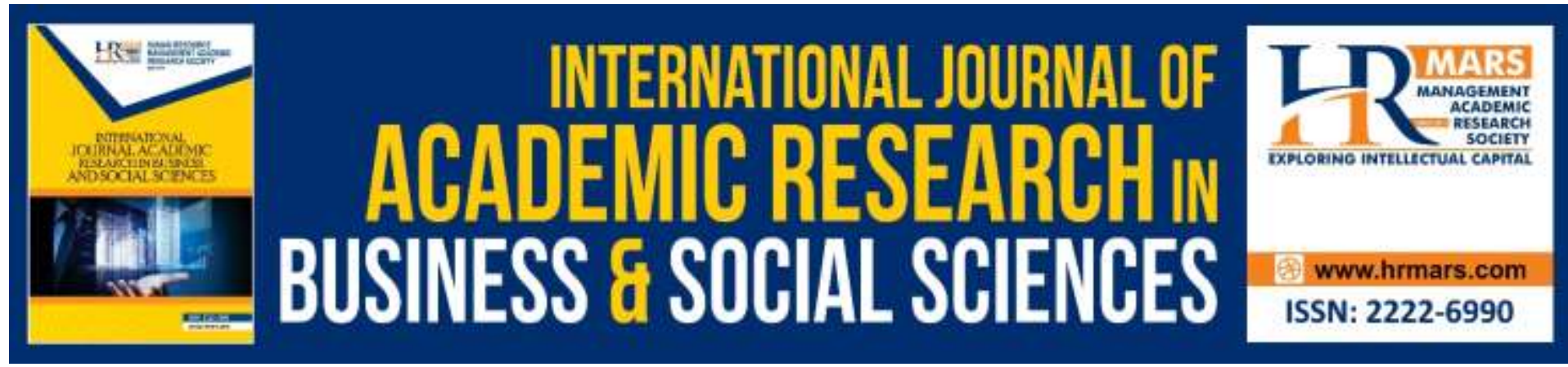

\title{
Framework of Empowering Mosque Institution in Malaysia
}

\section{Nizaita Omar ${ }^{1}$, Zulkifly Muda², Razi Yaakob³, Kasyfullah Abdul Kadir $^{4}$}

\author{
${ }^{1}$ Faculty of Islamic Contemporary Studies, Universiti Sultan Zainal Abidin (UniSZA) \\ Email: nizaitaomar@unisza.edu.my \\ ${ }^{2}$ Fatwa Department of Terengganu, Centre of Islamic Affair, Kuala Terengganu \\ Email: zulmuda66@gmail.com \\ ${ }^{3}$ Centre for Fundamental Studies, Universiti Sultan Zainal Abidin (UniSZA)
}

\begin{abstract}
Mosques are commonly associated with Islamic religious rituals such as salah, dhikr and du'a. They are also perceived as the prime location for celebrating Islamic festivals, and they physically are considered general places of worship for Muslims. For this matter, it should be understood that the word ibadah (religious rituals) itself is not restricted to the meaning of worshipping God. It has a broader definition which touches every procedure in every aspect of life which is to be executed with Islamic manners. This research, accordingly, will uncloak the role that mosques, particularly in Malaysia, play in contributing to the community transformation especially within Malaysian Muslims community. Also, a model will be proposed by which optimal participation and contribution can be presented by its potent status. Library research methodology is mainly used in this research, with focuses on every related written material found, either printed or electronic. Acts, statistics, official reports and other similar are analysed thoroughly for data collection. The findings show that the mosque should not be narrowly defined as a place to perform only worship but should also be seen as an agent for the transformation of society towards a better life in society.
\end{abstract}

Keywords: Mosque(S), Agent for Community Transformation, Empowerment, Betterment, Community

\section{Introduction}

Prosperity and prestige of the institution of mosque fully come from the Muslim community itself. Muslims within a nation carry a responsibility in making mosques a productive institution to serve their role as the agent for community transformation and mobility for religious and national interests.

It is time, which always is, for Muslims particularly in Malaysia (as relevant to the study) to act and put effort into mosques' productivity. Some of the mosques in Malaysia are being marginalized, and far from being involved in programs promoting life and community 
betterment. This should be contrary as mosques, as explained in the abstract, are not only meant for worshipping acts (ibadah) but also for every other act involving Muslims.

This research is done as an effort to remind people especially Muslims on the fundamental role of mosques as a universal social institution. A comprehensive study and awareness on the prominence that today's mosques can achieve if their role is played out correctly along with some examples of mosque models illustrated extensively are hoped to spark an aspiration among Muslims to turn them into reality.

\section{Problem Statement}

The principles and functions of mosque institution in restoring community development and mobility must be reinstated. This is essential as mosque institution plays a very significant role in forming and producing dedicated, progressive and visionary community.

Unfortunately today, the prestige of mosques is not manifest. Some of them are even disorderly and remain unfrequented most of the time especially outside prayer times (Asmak, 2007), with visitors mainly consist of people aged 40 and above (Omar, 2010). This small number of frequenters is imbalance with the big spaces and splendid facilities that these mosques offer, causing the people in charge to have quite a difficulty in coping with the management (Zaharuddin, 2007)

This is in line with the previous argumentation proposed by Siswanto (2005) who mentions that incovenient location, non-stimulating deliveries and weak management are among the reasons the mosque institution in Malaysia gradually weakens. Not only that, low supervision of human resorces and limited financial sources also contribute to this phenomenon.

What is saddening is some of these mosques are even left abandoned without maintenance (Zaharuddin, 2007). The failure of professional administration in managing them along with the administrative system itself, which is old and outdated, undermine their status as the centre of community development (Mohamed, 2007). It is evident that the function of mosques as the main source of life of a Muslim individual is no longer present as they only serve as places for religious ceremonies and ritual activities (Asmak, 2007).

\section{Literature Review}

There are several researches done by scholars on the empowerment of mosque institution's role. One of them is a comprehensive study specifically discussing on the roles and functions of a mosque by Fadli (2003). A similar study is carried out by El-Muhammady (1997) whose focus is on the philosophies, principles and concepts that mosque institution should follow to become prestigious in the future. 
Another related research is one done by Mohamed (2003) which analyzes the effort done by the Federal Territory Mosque in Kuala Lumpur to reinforce its status by organizing missionary work programs. Another research is also done by the Mohamed (1999) on a related topic which is the effectiveness of communal programs organized by mosques in empowering the community itself. This research particularly concentrates on mosques around Subang Jaya. These two researches, however, are more inclined to the management of programs within the mosques themselves and how they are found effective or otherwise.

Specifically choosing the district of Pasir Putih in Kelantan as the location for research, scholars Puhad and Rodhiah (2010) also focus their study on the quality of mosque management and administration. Similar topic but with more specific discussion on the technological aspect in mosques is formerly reviewed by scholar Ahmad (2007) and his group under the management of the State Islamic Religious Department of Selangor. Another subtopic that is given special attention to is financial management of the mosques which is examined by a group of researchers from the Department of Accounting, International Islamic University Malaysia (IIUM) (Alawiyah, 2007).

The outcomes that will be attained in this research is hoped to invoke the society or particularly the concerned parties to bring about a model mosque as a paragon to other mosques that will be built in the future, and consequently enhance the community transformation and mobility among the society.

\section{Objectives}

This research is hoped to accomplish these objectives:

1. Evaluating the position of mosques in Malaysia

2. Reviewing model(s) that can be implemented in the effort of empowering the position of mosques

\section{Methodology}

The methodology used in this study is mainly library research. Library research is considerably needed to obtain accurate information and clear understanding on the analysed topic. References on related books or any written sources are made to justify the concepts and theories proposed. The background of the existence and development of mosque(s) in the history of Islamic civilisation is analysed. Al-Quran and hadiths as the two primary sources of Islamic teachings are studied, along with academic reading materials such as journal articles, paperworks and books (printed and electronic) to help in scrutinizing and proposing the functions and roles of mosques for community betterment. To support the justifications made, documents including acts, statutes, circulars, statistics and official reports from authoritative parties are viewed.

\section{Results}

\section{Current Position of Mosques in Malaysia}

Legally, matters relating to mosques are under the administration of the state they are in. This is as stated in the Ninth Schedule, List 2 - State List in the Federal Constitution of Malaysia, quoted as below (Mohamad, 2011): 
"...Islamic law and personal and family law including the Islamic law relating to mosques or any Islamic public place of worship..."

Based on the statement above, it is clear that all mosques are under the management of their state with enactments and acts issued by their respective state's Islamic law administration. In Terengganu as an example, an enactment named the Enactment of the Administration of Islamic Religious Affairs (Terengganu) $1422 \mathrm{H} / 2001 \mathrm{C}$ is introduced to facilitate the administration of Islamic matters including those relating to mosques. The enactment is as below:

\section{A mosque as a building:}

(a) used for the purpose of salah and other Islamic acts of worship

(b) used as allowed by the Council under Section 82

(c) which includes surau (minor prayer spaces), madrasah (Islamic schools) and other buildings that are counted as mosques by the Council under the same section

As stated above, a mosque refers to a building that is constructed for the purpose of providing Muslims a place to perform ibadah and participate in Islamic activities.

In Malaysia, the evolution and development of mosques progress speedily. Mosques and surau can be found almost everywhere either in urban or rural areas. Not only that they are practical for ibadah, they also provide great facilities for locals and visitors in terms of their infrastructures and activities (Mohamed, 2007). Those who are in charge of this come from various groups depending on the levels of the affair. At the central level, all mosques' affairs are put under the concern of the Division of Family, Social and Mosque Management (KESUMA) which lies under the Department of Islamic Development in Malaysia (JAKIM) (JAKIM website).

In the state level, the management of mosques is under their respective State Islamic Religious Department or Islamic Religious Council. In Terengganu particularly, the Council of Terengganu's Islamic Religious and Malay Customs (MAIDAM) is appointed as the party responsible for the affairs of every mosque in Terengganu. To keep the affairs in view, MAIDAM has obligated every mosque that is to be built (for the purpose of conducting Friday prayers) to get a written consent from them. This is done to regulate the institution of mosque as a whole and ensure that every mosque in the state follows the benchmark set by them in order to dignify the mosques themselves and maintain the unity among Muslims in the long run. This is asserted in the Section 80(1) as below:

No one may, without any written consent from the Council to construct a building for use, or use or cause any building to be used, for matters that can only be performed in mosques.

The assertion above strongly proposes that no one may build a mosque or perform Friday prayers in a building arbitrarily without refering and obtaining a written consent from MAIDAM. 
There are nonetheless non-governmental agencies that are held responsibility in mosque construction. Yayasan al-Bukhari is one of them, which has built several mosques in northern and southern Malaysia and stays at the helm of their administration. There are also other agencies who orginally serve as housing developers choosing to contribute to social advantages by constructing mosques and surau.

According to Ajmain (2007), the participation from the local community in programs and activities organized by the mosques has lessened. This phenomenon obscures the roles and functions of the mosques to the public. This happens for a number of reasons including:

(1) Improvident management leadership and lack of activities' enhancement

(2) Incompetent programs and activities, and their irrelevance to the group target

(3) Non-stimulating deliveries either resulted from ineffective presenters, methods or irrelevant topics

(4) Lack of physical attractiveness of the surroundings, and poor standards of hygiene especially in the bathrooms

(5) Social development schemes are not user-friendly, youth-friendly and family-friendly

Abdurrahman (2004) has propounded the differences between the functions of mosques in current time and in the early time of Islam. The differences are clearly presented in the table below:

Table 3: Comparison on the Roles of Mosque in Current Time and the Early Time of Islam

\begin{tabular}{|l|l|}
\hline Early Time of Islam & Current Time \\
\hline Centre of Ibadah (Acts of Worship) & Centre of Ibadah (Acts of Worship) \\
\hline Centre of Life Formation & Centre of Community Education \\
\hline $\begin{array}{l}\text { Centre of Tarbiyah (Education and } \\
\text { Upbringing) and Good Personality } \\
\text { Development }\end{array}$ & Centre of Islamic Values' Fostering \\
\hline Centre of Ummah (Community) Unity & Centre of Information and Resources \\
\hline
\end{tabular}

Source: Abdurrahman (2004)

It is time for Muslim community in Malaysia to act and proactively put some effort in empowering mosque institution. Mosques, wherever they are, must not be marginalized, instead they should be included in every aspect of government plans so that a quality community can be produced. They should not be made as places of worship only but as the centre of community life extensively. The word 'mosque' itself should be definably regarded as the religious centre, resources centre, social service centre, economic centre and education centre all in one.

\section{Model of Mosque Empowerment for the Agenda of Muslim Community Betterment}

In the framework of empowering mosque institution, a few strategies or steps must be taken. The following are the aspects that need to be given thought to in this effort of mosque empowerment: 


\section{(a) Professional Administration}

Administration refers to a set of activities that is specifically arranged to instruct and progress certain tasks (Atory, 2002). The adjective professional denotes specific ability and skills within a person to perform relevant task(s) proficiently (Baharom, 2005). So, the professional administration in the context of mosque institution may be defined as a system of management that is efficient and systematic that is executed for the purpose of achieving the objectives and visions of the mosque institution itself.

Human resources are the main asset in an organisation. Manager(s) and staff of an administration must possess high character of professionalism. The institution of mosque should as well consists of professionals or at least qualified individuals who have adequate knowledge and skills for their tasks. Training or course(s) such as leadership course, administrative course, financial course, office management course and filing course for the staff is required to ensure the whole operation to go smoothly. Efficient office spaces with

Management control needs to be administered professionally and systematically. A manual on work procedures must be prepared to act as the guidelines for every operation and activity organized (Yaakob, 2008). They should be expected to fill in the Annual Work Target at the beginning of the year as a planning draft of what they will accomplish throughout the year followed by the Annual Performance Assessment Report at the end of the year to assess them based on their achievement. To actualize professional administration in mosque institution, a quality recognition such as the certificate of International Organization for Standardization (ISO) from the authoritative agency Standards

and Industrial Research Institute of Malaysia (SIRIM) can be attained as the quality of the management will be monitored regularly by the agency through annual audit.

\section{(b) Professional Planning on Programs/Activities}

Every activity that is about to be organized needs to be rechecked in terms of its suitability and effectiveness on the community. As a knowledge centre, mosques should take a step forward from their traditional role of providing religious talks. They can probably organize formal education program(s) that is equal to a certificate or a diploma so that the participants will get more advantages than just merely listening or being informed. A collaboration with higher education institute(s) might as well help actualizing this.

Universal programs such as seminars and forums with discussion on current issues by Islamic scholars and experts of certain areas are beneficial to be conducted in mosques to provide the community with bigger perspectives and views on what is happening around them. Also, social activities like Family Day or A Day with the Mosque are healthy to be organized as it accommodates the bonding within a local community.

Programs or activities offered must be relevant to every age group. This is important to attract every individual of every age level to come and participate in religious and social activities. For those of teenage age especially, activities that are organized for them must be relevant and complying with their interests such as futsal tournament, as well as facilities like recreational parks or spaces and internet access. As for individuals who have any issues or 
trouble going on in their lives, the mosques themselves need to provide a special space for counselling along with counselors and every material needed. A library should also be built

inside the mosques so that community especially kids can get the advantage from it by reading and doing other stimulative activities.

Lastly, to give $d a^{\prime} w a h$ a better efficiency, more publication of books and regular updates on the mosques' websites need to be assured.

\section{(c) Professional Physical Features}

A mosque needs to have comfortable and clean space(s) for ibadah and other activities as well as pleasant and attractive landscape as a symbol of its prestige.

Mosque library is one of the important facilities that a mosque needs to have for it to serve the function as the centre of knowledge. The purposes of having a library inside a mosque are to cultivate the love and passion for Islamic knowledge, to make reading a habit among the community, to spread the teachings of Islam extensively and to support the education of Muslims by providing materials from various disciplines. Not only that these libraries act as a centre for Islamic knowledge, they also serve as a centre for education, recreation, sociality and research (Roziya Abu, 2008).

As touched upon above, mosque institution needs to provide easy access on information and communications technology (ICT) within its system. This is so the administration or management of a mosque is handled professionally with current technology.

\section{(d) Professional Financial Management}

Professional financial management is very essential in ensuring the development and progress of an organisation. It involvess the process of decision making that needs thorough planning, supervision and fund use in order to attain the objectives and visions (Alawiyah, 2007).

In ensuring the efficacy and efficiency of the financial source used, the accountability of the parties involved should be observed. In order for the management of fund to go faultlessly, a committee within a mosque should be formed.

\section{Conclusion}

The excellence of mosque institution depends fully on the community's support. Efforts and cooperation of all parties, from the government to the local cummunity, are essential to empower and reinforce the status of mosques in the national or even global level, and consequently restore the prestige of Islam. To put it conclusively, mosques can be seen as a power generator that flows the electric power to every home connected with it. They are considered as the hearts for the ummah (Muslim community), of which will become null if they stop functioning. 


\section{Acknowledgement}

Highest appreciation is given to Universiti Sultan Zainal Abidin for the sponsor provided for this research through the University Research Grant Funds 2017 - R0009-360.

\section{Corresponding Author}

Nizaita Omar, Faculty of Islamic Contemporary Studies, Universiti Sultan Zainal Abidin (UniSZA), Gong Badak Campus, 21300 Kuala Nerus, Kuala Terengganu, Terengganu,Malaysia. Email: nizaitaomar@unisza.edu.my

\section{References}

Mohamad, A. (2011). Kajian Penilaian Program Pemantapan Akidah di Masjid Negeri Terengganu, Doctoral Thesis of Universiti Malaysia Terengganu

Haqqi, A. R. A. (2004). Peranan Masjid Masakini: Satu Penilaian Berkaitan dengan Kedudukannya sebagai Wadah Kepimpinan Raja, Paperwork for the Seminar of Mosque Institution organized by the Department of Prime Minister of Brunei held on 19th to 21st of July 2004

Atory, A. (2002). Pengurusan Organisasi, Kuala Lumpur: Utusan Publications \& Distributors Sdn. Bhd

Yaakob, A. N. (2008). Manual Prosedur Kerja (MPK): Ke Arah Memantapkan Pengurusan Masjid, in the book Pengurusan Berkualiti Memacu Kecemerlangan Masjid, Skudai: UTM Publication

Alim, A. P. \& Abdullah, S. R. (2010). Audit Pengurusan Masjid: Kajian Di Daerah Pasir Puteh, Kelantan, Faculty of Education, Universiti Teknologi Malaysia

Sabri, A. Z. S. A. \& Noor, M. R. M. (2007). Peranan dan Kepentingan Pengurusan Sumber Manusia dalam Pengurusan Masjid, Paperwork for National Seminar of Mosque Management organized by Sultan Ismail Mosque of UTM and Foundation of Islamic Dakwah in Malaysia

Ajmain, J. S. (2008). Institusi Masjid dalam Memperkasakan Modal Insan, in the book Pengurusan Berkualiti Memacu Kecemerlangan Masjid, Skudai: UTM Publication

Ali, A. \& Said, H. M. (2007). Peranan Masjid Dalam Masyarakat Hadhari. Paperwork for National Seminar of Mosque Management organized by Sultan Ismail Mosque of UTM and Foundation of Islamic Dakwah in Malaysia

Ismail, M. F. (2003). Peranan Masjid, Kuala Lumpur: Darul Nu'man

El-Muhammady, M. U. (1997). Instituís Masjid yang Bersifat Futuristik, Paperwork for Convention of Mosque Empowerment held in Pan Pacific, Kuala Lumpur on 30th of January 1997

Omar, N. \& Muda, Z. (2010), Tahap Pengetahuan dan penguasaan Ilmu Qiraat dalam kalangan Masyarakat Awam Terengganu, Paperwork for International Seminar of Qiraat and Qurra' held in Universiti Sultan Zainal Abidin (UniSZA)

Momin, N. (2003). The Role of Mosque Library in Supporting the Development of Islamic Knowledge and Information among the Community: A Case Study at Al Azim Library, Bukit Palah Malacca, Thesis of Faculty of Information Studies, Universiti Teknologi Mara

Baharom, N. (2005). Kamus Dewan, Kuala Lumpur: Dewan Bahasa dan Pustaka

Mohamed, R. (1999), Keberkesanan Program Masjid Dalam Membina Identiti Masyarakat Islam: Kajian Di Masjid-Masjid Subang Jaya, Selangor Darul Ehsan, Universiti Malaya 
Mohamed, R. (2003). Keberkesanan Program Masjid: Kajian Umum Masjid-Masjid Di Wilayah Persekutuan Kuala Lumpur' Dalam Membangun Institusi Masjid. Kuala Lumpur: Intel Multimedia and Publication

Mohamed, R. (2004). Memperkasa Masjid Sebagai Institusi Pembangunan Insan. Paperwork for National Seminar of Mosque Management held on 25th to 27th of September 2004 organized by Universiti Utara Malaysia

Mohamed, R. (2007). Memperkasa Masjid Melalui Pengurusan Profesional. Paperwork for National Seminar of Mosque Management 2007 held on 28th to 29th of April 2007 organized by Universiti Teknologi Malaysia

Abu, R. (2008). Perpustakaan dalam Masjid Satu Tinjauan, dalam buku Pengurusan Berkualiti Memacu Kecemerlangan Masjid, Skudai: UTM Publication

Siswanto (2005). Panduan Praktis Organisasi Remaja Masjid, Jakarta: Pustaka al Kauthar

Siraj, S. A. (2007). Pengurusan Kewangan: Mempamerkan Akauntabiliti Masjid Negeri di Semenanjung Malaysia, Paperwork for National Seminar of Mosque Management in Peninsular Malaysia organized by Sultan Ismail Mosque of UTM and Foundation of Islamic Dakwah in Malaysia

Ahmad, Y. (2007). Kajian Tahap Kemudahan Dan Penggunaan Audio-Visual Dan Komputer Di Masjid-Masjid Bawah Kelolaan Jabatan Agama Islam Selangor (JAIS)- Satu Kajian Awal, Universiti Sains Islam Malaysia 